\section{Apocalypse without End}

\author{
Morton D. Paley: Apocalypse and \\ Millennium in English Romantic Poetry
} (Oxford: Clarendon Press, 1999)

After his many studies on individual authors and poems, Morton D. Paley in this book tackles a much broader subject: the topos of "the imminence of an apocalypse that will be succeeded by a millennium" in English Romantic poetry. His book is a conclusion to an especially fruitful career (on Blake, Blake's Jerusalem, Coleridge's later poetry and English Romantic painting, to mention only a few of his most important works) and is a synthesis of present-day Romantic scholarship, reformulating earlier questions and introducing considerations that will allow a new whole to be constructed out of them. However, as a book on the 'End' necessarily shows, a conclusion is very often also a beginning and a middle. Paley's work is, similarly, a synthesis as well as a continuation and - hopefully - a new beginning in the author's career.

The questions raised in Apocalypse and Millennium in English Romantic Poetry are firmly rooted in a critical tradition that Paley himself has contributed to create. More closely, his project is based on M. H. Abrams's definition of Romanticism as the age of secularisation of biblical paradigms. "Much of what distinguishes writers I call 'Romantic,'” Abrams writes in his fundamental book Natural Supernaturalism, "derives from the fact that they undertook, whatever their religious creed or lack of creed, to save traditional concepts, schemes and values which had been based on the relationship of the Creator to his creation, but to reformulate them within the prevailing two-term system of subject and object, ego and non-ego, the human mind or consciousness and its transactions with nature." ${ }^{1}$ By examining how "apocalypse and millennium are envisaged on the historical plane, in nature, or within the self" in Romantic poetry (p. 2), Paley follows the Abramsian thesis - a statement that has by now become one of the most traditional (and questionable) starting points in Romantic studies.

Paley's reading of some of the texts, however, seems to contradict the overarching Abramsian definition. For instance, secularisation becomes highly dubious with relation to Blake, whose prophetic books - according to an earlier remark by Paley - combine 'literal,' 'allegorical' (historical), 'moral' (psychological) and 'anagogical' (cosmic) layers of meaning. ${ }^{2}$ By focusing on particular poems, Paley allows the texts to contradict in similar manner general statements about Roman- 
ticism. He is very often ready to emphasise the 'otherness' of a text such as Byron's "Darkness" (a poem that does not preserve biblical schemes but offers an alternative to them). This is because Paley does not intend to reach any clear-cut definition himself; he is much more content with calling attention to ambiguities in the texts and to critical disagreement in their reading. A typical example of this method is his treatment of "The Stone and the Shell" episode in Wordsworth's The Prelude. After comparing diverse interpretations of the passage (according to which Imagination is either threatened by apocalyptic forces or is an apocalyptic force itself), he concludes that "they could be viewed as providing several related vantage-points on the "deluge now at hand'" (p. 164). He also refers to approaches (like feminism) that are outside his scope; in this way he does not suppress but provokes further thinking on the reader's part.

Paley's fondness of indeterminate meanings and open-ended questions suggests his indebtedness to deconstructionist thought. However, the approach that most influenced his basically traditional (Abramsian) work is New Historicism. Even though he does not adopt a New Historical theory of history, he relies on achievements of New Historicism (works by
Nicholas Roe and E. P. Thompson, among others) to a great extent. The subject matter of his book almost predestines him to do so, for apocalypse in English Romantic poetry is, without exception, linked to the French Revolution, the apocalyptic experience of the period. Paley is very careful to map - with the help of historical works and New Historicism - the English ideological climate before, during and after the Revolution, paying special attention to the shifting evaluation of the events that explains their shifting representation in Blake, Coleridge, Wordsworth and later Byron, Shelley and Keats. By pointing out the inconclusiveness of revolutionary experience, he is able to explain why the French Revolution appears as an endless apocalypse in many Romantic texts. He also reconstructs the literary debate between radicals and conservatives over the 'proper interpretation' of the Revolution and calls attention to intertextual links between these argumentative books and pamphlets (Burke's Reflections, for instance) and the poems he deals with.

The questions raised by Paley are complex and difficult to handle. Not only because political and ideological features of the age and their manifestation in works of art are complicated problems, but also because political aspects are inextricably linked to theo- 
logical-philosophical and literary problems: these together determine the construction of apocalypsemillennium schemes in literary works. All the three aspects are many-faceted in themselves, and thus all of them must be handled delicately. To mention just the most important, neither apocalypse nor millennium can receive a straightforward definition that could be used throughout, because the two themes are represented in several different ways in the Old and New Testament with and without each other. Paley chooses to rely primarily on the apocalypse-millennium scheme of the Book of Revelation - however, this book is itself "a work that seems to offer total vision and structural wholeness but that actually dissolves into fragments in reading." ${ }^{3}$ The conceptual framework becomes even more fragmentary when we consider how many kinds of interpretations have been proposed for the Book of Revelation. M. H. Abrams names the literal and the spiritual approaches, ${ }^{4}$ while Kermode distinguishes between an imminent and an immanent End. ${ }^{5}$ Paley follows both of these critics when he shows that Romantic adaptations of the pattern tend to shift from external to internal interpretations. However, by doing so he has to ignore problems that cannot be explained by the concept of internali- sation - Blake's claim, for instance, that "the Last Judgement is not a Fable or Allegory but a Vision" (E 544) remains uninterpretable in these terms. $^{6}$

Beside addressing questions of history and theology, Paley has to account for an enormous amount of literature in and about the apocalyptic mode; works that - like Milton's Paradise Lost - greatly influenced Romantic treatments of the theme. After these comes the real kaleidoscope: the chaos of Romantic renderings of the topos. The permutations that Paley examines seem to follow as many strategies as intertextuality can; they vary from prophetic affirmation of apocalypse and millennium (Blake: Jerusalem) to satire of contemporary society (Coleridge-Southey: 'The Devil's Thoughts'), from reluctant prophecy (Coleridge: 'Ode on the Departing Year') to ironical negation of apocalyptic knowledge (Byron: Cain) and a mocking of millenarian beliefs (Byron: Don Juan, III). In between, there are the fascinating border cases such as Shelley's Prometheus Unbound or Keats's Hyperion, fragments that simultaneously affirm and reject apocalyptic revelation. Such a wide range of texts cannot be handled together; this is why Paley reads each poem separately and analyses the apocalypse-millennium relationship 
anew in each particular case. As a result, his book is slightly fragmentary, but this quality reflects the important characteristic of his subject matter.

The framework of the book - the concept of 'Romantic poetry' - is not less elusive than the apocalypsemillennium pattern. However, Paley relies on the traditional notion of Romanticism as a coherent whole; he does not take into account that the movement has started to dissolve into several different 'Romanticisms' for contemporary critics and has even been claimed to be "a posthumous movement," a projection into the past. ${ }^{7} \mathrm{He}$ uses the traditional concept as a working tool without further justification or questioning of its validity. Similarly, he does not reconsider the relevance of the canon. Even though many critics have proposed different classifications of the authors or insisted on an expansion of the canon, Paley deals with only the canonised six 'masters' of Romantic poetry. Even his passage on Mary Shelley one of the most important and fascinating parts of his book - remains an addendum to the chapter on Byron.

The structure of the book is based on this traditional concept of Romanticism: one chapter for each of the six 'masters.' However, Paley does not intend to give a full picture of the career of these poets. He focuses on a few works by each poet that possibly have apocalyptic or millennial associations (although, as I have mentioned, the definition of 'apocalyptic' and 'millennial' remains the most important question of the book). The chapters on Blake and Coleridge (Paley's earlier field of study) offer the most detailed readings, while the chapter on Keats is rather a raising of questions and introducing suggestions than a complete analysis. The slightly unbalanced and rigid structure of the book is corrected by frequent crossreferences between the chapters; in this way the poems appear not as isolated enterprises but as interrelated units that may participate in the same (radical) discourse and echo or contradict each other in many ways. One of the most fascinating motifs that Paley follows throughout his readings is the image of the snake; it is an emblem of the Fall and of Evil but also an emblem of Christ, a symbol of recurrence (the snake biting its tail, or the ourobouros) but also of bursting out from the cycle of history (the twoheaded amphisbaena); it is also a popular revolutionary symbol - related to apocalypse either as a political, or as a theological or philosophical concept in many ways. Its frequent occurrences create a link between several texts that Paley deals with, while the distinctions among its various mean- 
ings make this a thread as intricate and winding as the snake itself.

The greatest merits of Paley's work lie in his careful and thorough method of 'uncoiling' such serpents. $\mathrm{He}$ collects relevant material with the utmost care for all the poems he examines, turning to previous critics (sometimes questioning their validity), and adding to them his own findings. In this way, he reconstructs several relevant contexts for each poem (the political, ideological, biographical and intertextual surroundings of a work, for instance) and interprets the apocalypticmillennial scheme of the poem in the light of these contexts. His method sometimes resembles that of an archaeologist: he pieces together details and evidence with extreme accuracy. His findings are, similarly, sometimes as solid and valuable as those of an archaeologist (his new interpretations for the name 'Demogorgon' in Shelley's Prometheus Unbound).

One feels that some scepticism is lurking behind this method that makes Paley's work akin to neopositivism. It seems that he doubts whether criticism can arrive at any valid generalisation about Romanticism and goes on to use traditional concepts because he cannot be certain that the new generalisations are any better. This scepticism has undoubtedly been motivated by the diverse and elusive nature of Romantic poetry and by Paley's great familiarity with Romantic thought. He does not want to lose the details for the sake of abstractions. He does not want to put an end to a debate that is inherently endless. The coherence and reliability of this approach makes his book both valuable and a refreshing reading among many contemporary works that offer ground-breaking concepts without self-criticism and accuracy.

VERONIKA RUTTKAY

\section{NOTES}

${ }^{1}$ M.H. Abrams. Natural Supernaturalism. New York, London: W. W. Norton, 1971, p. 13.

${ }^{2}$ Morton D. Paley. Energy and Imagination: A Study of the Development of Blake's Thought. Oxford: Clarendon, 1970, p. 63.

${ }^{3}$ Christopher Burdon. The Apocalypse in Eng. land: Revelation Unravelling, 1700-1834. Basingstoke: Macmillan, 1997, p. 29.

${ }^{4}$ Abrams. Natural Supernaturalism, pp. 56-65.

${ }^{5}$ Kermode. The Sense of an Ending. Oxford: Oxford UP, 1966, p. 25.

${ }^{6}$ The Abramsian concept of internalisation has been called into doubt by many critics, most recently by Christopher $\mathrm{Z}$. Hobson in his The Chained Boy: Orc and Blake's Idea of Revolu. tion. Lewisburg: Bucknell UP, London: Associated Ups, 1999.

7 Marilyn Butler. Romantics, Rebels and Reactionaries. Oxford: Oxford UP, 1981, p. 2. 